\title{
Sociolinguistic Awareness of Spanish Speakers on the Mexican Border with Belize
}

\author{
Raúl Arístides Pérez Aguilar \\ Division of Political Sciences and Humanities, Mexican Academy of the Language, Mexico; \\ Department of Humanities, University of Quintana Roo, Mexico
}

\begin{abstract}
The border society of Chetumal is studied in order to know how the speakers of this linguistic community conceive their ways of speaking Spanish in different situational contexts (home or work), before different people (employers, friends or subordinates) and with it get to check the degree of linguistic awareness they possess; that is, if the social boundaries present in their speech exist and are recognized as such by all speakers. This study is based on just over 100 questionnaires applied to the same number of Spanish-speakers born in Chetumal in 2019, who were registered according to the traditional sociolinguistic factors of age, sex, and socio-cultural level, the latter calculated basically on the individual's education index. The conclusions reflect the linguistic reality of Spanish speakers on the southern border of Mexico in which Caribbean and English elements are palpable in the lexical sector of the language.
\end{abstract}

Index Terms - chetumal, border, Belize, Spanish, sociolinguistic awareness

\section{INTRODUCTION}

The dialect complex of Spanish, already detected through the awareness of notable differences in regional or community languages, is not easy to determine historically. The history of culture - in which the social history of the language must necessarily be embedded - still keeps little-traveled nooks that must be studied in parallel with the language manifestations of those who have formed and structure the various linguistic communities ${ }^{1}$ in the present.

In this dialect complex, contemporary dialectology and sociolinguistics cannot only establish boundaries between geolects and sociolects, but also verify this complex and real diatopic and diastratic configuration of a language state. In other words, it must present an analysis of linguistic phenomena not only rural - such as traditional dialectology - of a diatopic character, but also of the diastratic and diaphasic varieties - more unstable than the diatopic and diachronic ones - in which the linguistic variation contains a fortunate description that makes use of extralinguistic correlations and statistical sampling methods.

In this sense, a dialectology and a sociolinguistics must be considered that presents not only the phenomena - lexical, morphological, phonetic and syntactic - on maps, but also pays special attention to social and contextual variation and to the urban varieties in which standardized ${ }^{2}$ and vernacular ${ }^{3}$ forms necessarily coexist.

The social background of the linguistic phenomenon is undeniable. Thus, today throughout the world, the structure of human communication cannot be studied by the scientific community as an abstract entity, but rather as a social interaction in various contextual situations. The word names and designates, and in doing so it inclines the speaker's attention to the thing it names, to the object, action, or life experience; However, the word also means, and at the precise moment of using it it brings to the memory of the speaker the components of these socially shared meanings (which are usually multiple) that give it a relevant meaning for the society that uses it (Lara, 2016, p. 213).

The well-known reflection of Vicente García de Diego (1946), who says that the language is a vast complexity of geographical dialects and an overlap of social dialects is extremely illuminating if we observe the versatility of any idiolect: that of the government employee, the university professor or the peddler who express their speech in different contexts: formal or informal, in different ways.

However, there should be no shortage of those who say that he expresses himself in the same way before an administrative authority as before his friends in a less formal situation; but this is no basis for defending the uniformity of his speech, but rather evidence of his lack of linguistic awareness. However, not all speakers think this way. It is clear to many - and they are the majority - the difference between "bad speaking" and "good saying", especially due to the lexical or phonetic manifestations of other speakers who are usually described as vulgar "bad spoken" or possessors of a great eloquence respectively.

1 A linguistic community is understood as the group of individuals who use the same language (or geolect) at a given time, and allow them to communicate with each other

2 A standardized form is that used in an accepted language that serves as a model for a relatively large community. In this sense, one of the functions of the standard language is to unite the speakers of different geolects in the same language and thus oppose them to those of other languages

3 Vernacular forms are non-normalized elements (not recognized by other communities) whose function is to serve as a means of expression in informal or family communicative situations, they are forms acquired in childhood, heteronomous social varieties that must be studied, as well as the standardized forms, in light of social groups and contextual situations. 
Sociolinguistic consciousness refers to the knowledge that the speaker possesses about the organization of the entire sociolinguistic spectrum in which you have immersed yourself as a member of a certain speech community (García, 2019, p.17).

Now, how aware are these speakers of the variation of the speech of their countrymen and of themselves? If the linguistic variation is evident, what does this situation have to do with the social structures of a speech community?

In communication, the immediacy of dialogue flows because the speaker expresses the learning he has of his language, of the meaning that words have of their socially accepted use and of socially forbidden words, of what situational contexts impose on his speech and his own transit through popular, colloquial and cultured forms of the language even though he is not fully aware of all this. And this itself makes it safe from all questioning and from all wanting to see in it a user who sometimes makes mistakes and falls into the incorrectness because he commits faults to the Hispanic tradition by misnaming a verb, for example and saying imprimido by impreso or saying hubieron muchos invitados instead hubo muchos invitados.

We know that speakers are aware of a series of linguistic and sociolinguistic facts, because they know that in their community some linguistic uses are preferred over others according to the interests one has when speaking. This faculty of choice comes from a linguistic awareness, which is decisive when the phenomena of linguistic variation and linguistic change occur (Falcón and Mamani, 2017, p. 98).

\section{The OBJeCtives}

The objective of this study is the analysis of Chetumal Spanish $^{4}$ as it is conceived by the same speakers of the linguistic community, in order to be able to check the degree of linguistic awareness they possess; that is, if the social borders present in their speech exist and are recognized as such by all Chetumaleños.

The methodology used for the selection of the informants was based on the following aspects: the selection was random, the speaker had to meet certain requirements such as being a native speaker of the city or having lived in it $75 \%$ of his life, have parents from the city or the Yucatecan region, be over 18 years of age and live in a specific area of the city with a long population tradition.

This study is based on just over 100 questionnaires applied to the same number of Spanish-speakers born in $\mathrm{Chetumal}^{5}$, who were registered according to the traditional sociolinguistic factors of age ${ }^{6}, \operatorname{sex}^{7}$, and sociocultural level ${ }^{8}$, the latter calculated basically on the individual's education index ${ }^{9}$.

Three turn out to be the objectives broken down:

1. Analyze the general sociolinguistic awareness of Chetumaleños to establish relationships between ways of speaking and social structure.

2. Analyze the sociolinguistic norm or the habit of everyday speech as established by the respondents.

3. Analyze positive or negative attitudes towards the variants of local Spanish and their current and future influence.

Despite the fact that there is no effective method by which the degree of sociolinguistic awareness in the minds of speakers can be measured, there is no doubt in it that there are differences in the way people speak. And even less so in the researcher, who through a procedure that gives validity to the evaluation made by the speakers of the social aspects of the language, will objectively judge the linguistic variation studied by him.

Faced with this absence, a questionnaire that Hugo Kubarth from the University of Graz, Austria designed and applied to a hundred inhabitants of Buenos Aires in 1983 was adapted ${ }^{10}$. Its invoice is based on open questions, on

\footnotetext{
4 The case of Chetumal is unique because it was not properly the seat of Canaries only, but of many Bacalareans, Yucatecans and their children, mostly who, inheritors of the Mayan, yukatecan and Canary forms, grew up or were born in British Honduras (now Belize) and who, invited to return to their homeland for Admiral Othón P. Blanco, they founded Payo Obispo (today Chetumal) in 1898, as their parents or themsel ves, as in the cases of the codfish Francisca López and the Valladolid Fernanda Briceño (my great-grandmother), left from Bacalar in 1858 due to the Mayan revolt against the whites (known as the Caste War) and they settled on English soil under the protection of the Royal Crown. (See Pérez,2016). The nascent border city had, in 1904, a population made up of 248 inhabitants of which 205 were Spanish-speaking and of these 180 were Yucatecans or descendants of them $(87.8 \%)$. In that small space of Mexican soil, the Yucatecan language took root along with the Canarian heritage without its users realizing it. It is worth mentioning that the Yucatecans and their descendants who decided not to return to Mexico continued to plant their linguistic forms in the south of the Hondo River in towns such as Orange Walk, Corozal, Sarteneja, San Román, San Esteban, Xaibé and others, or they continued to arrive to Chetumal for the next 5 decades. Currently immigration continues on a smaller scale legally and illegally. (For more details see Vallarta,2001, 74 and annexed 2).

5 The questionnaires (100) were applied in 2019, but only those of 60 individuals were useful since several of them did not meet some of the essential requirements for this type of study (being born in the city of Chetumal parents or from the Yucatan peninsula or have a residence of $75 \%$ of their life in the city, live in a certain area of the city with a long population tradition); However, the sample is representative of the different sociolinguistic factors that were taken into account.

6 Young people: 18 to 30 years old: 30 respondents; mature: 31 to 50 years: 20 respondents; elderly: over 50 years: 10 respondents.

732 women and 28 men turned out.

8 Lower class: up to primary: 24 informants; middle class: up to high school or short career: 18 informants; upper class: studies after high school: 18 informants.

9 Of course, there are other ways of calculating belonging to a certain social sector, such as the income of money in the family, the place of residence and the occupation. The income was not recorded but the occupation and place of residence were not. 17 professionals, 10 students, 11 housewives, 4 merchants and 18 people of various trades were surveyed: blacksmiths, policemen, secretaries, saleswomen, carpe nters, watchmen, etc. Furthermore, the distribution of informants in popular, elegant and middle-class areas was more or less homogeneous: $35 \%$ in popular areas, $33 \%$ in middle-class areas, and $32 \%$ in elegant areas of the city.

10 This is found in "La lengua como juego social. Conciencia sociolingüística del porteño", Thesavrvs, XLI, 1986, p. 187-210.
} 
others in which the respondent is provided with options , and in some that - given their imprecision - they served a lot to collect attitudes of the speakers and reflections on the linguistic phenomenon in question.

\section{QUESTIONNAIRE}

The questionnaire applied is as follows:

1. In Mexico there are differences in pronunciation that could be classified with the following scale: affected (A) or careful $(\mathrm{E})$, normal $(\mathrm{N})$, popular $(\mathrm{P})$ or vulgar $(\mathrm{V})$ pronunciation. Is the same thing happening in Chetumal?

2. Based on the scale above, how do you think a secretary speaks?

3. According to the scale above, how does a doctor speak?

4. According to the scale above, how does a minibus driver talk?

5. Is there a neighborhood in Chetumal where people speak especially badly?

6. Would you like to live in that neighborhood?

7. According to the previous scale, how is it spoken in the Campestre neighborhood?

8. According to the previous scale, how do you speak in the Solidaridad or Proterritorio colonies?

9. On local television and radio, are there programs in which a particularly popular or vulgar Spanish is spoken?

10. According to the scale above, how do you speak at work?

11. According to the scale above, how do you speak at home?

12. Did your parents teach you how to pronounce or speak?

13. Does this seem important or necessary?

14. Do you recognize a Yucatecan son born in Chetumal by any particularity of his speech?

15. How do you recognize a tourist from the Federal District by their speech?

16. Do you know what maya is?

17. Who speaks that language?

18. What is "bludgeoned" speaking?

19. Who talks like this?

Before detailing each of the questions, it is necessary to clarify that $96.7 \%$ of them were answered. In other words, 1102 of the 1140 questions answered show the interest of those surveyed in giving an answer to the problems that arose. Even the poorly educated social class showed a broad disposition for linguistic reflection.

Furthermore, on several occasions the informants not only dedicated themselves to answering the questionnaire, but also issued additional information to what they were asked, thus demonstrating, once again, their interest in the linguistic phenomenon ${ }^{11}$.

\section{THE ANSWERS}

The first question was answered in the affirmative by all the informants. However, apparently it was understood by several of them in a wrong way, since they perceived that they were being questioned about dialect and not social differences. That is to say, these speakers undoubtedly perceived different pronunciations in people from Veracruz, the Federal District or Yucatán and were unaware of the diastratic value of what they were being asked. However, the answer shows that the diatopic variation of the Spanish language is clear to them. For others, the diastratic variation is also evident, as a doctor can "speak naturally and fluently", way". Even in several, the reflection on the diaphasic aspect of the tongue is perceived, since the same doctor who "speaks naturally and fluently" can be "disgustingly vulgar and offensive depending on the person with whom he speaks. ${ }^{13 "}$

Questions 2, 3 and 4 have the purpose of perceiving the social classification in three strata: high, medium and low, and at the same time to evaluate the position of these social layers in front of the others and in front of themselves. To help the informant, the scale indicated in the previous question was repeated.

In order to make the analysis of these three questions simple, we will group the terms "affected and careful" (AE) on the one hand, and "popular and vulgar" (PV) on the other, leaving the normal modality in the middle box (N).

In the case of the secretary (question 2), the majority rated her speech as normal (N), 22\% opted for A-E and $23 \%$ for $\mathrm{P}-\mathrm{V}^{14}$. The doctor's speech was classified as A-E by $60 \%$, as normal by $35 \%$ and only $5 \%$ said that it seemed P-V,

11 This work would undoubtedly improve if a more extensive questionnaire were applied that would include in its structure variables such as: (single / married / widowed / divorced, illiterate / literate, native / foreign, bilingual / monolingual, office worker / street worker, in addition Variables that would complement the knowledge of sectors of society if relative questions were added about the speech of women, men, the speech of wives, the speech of husbands, of bosses, the speech of the merchants, the masons, the servants, the teachers, etc., which would rethink new objectives that seek to capture the sociolinguistic consciousness of the speakers and open the way to new investigations into the dialect and idiolectal uses of the language.

12 The comment belongs to a 53-year-old woman with a university degree.

11 Answer from the same person in the previous note.

9 The comment is from a 55-year-old woman with graduate studies.

14 "In his work, he tries to speak, but with friends he speaks vulgar." This is the opinion of a 20-year-old low-level woman. 
because "there are also vulgar and offensive ones ${ }^{15}$ ". Here there is more homogeneity in the results. However, the speech of the minibus driver was considered as $\mathrm{P}-\mathrm{V}$ by $85 \%$ of the respondents ${ }^{16}$, an evaluation in which it was not perceives a noticeable hesitation towards the extremes of the proposed scale, as occurs with the speech of the doctor and the secretary.

That is, according to these global results, each of the representatives of each social class corresponds to a specific way of speaking. Now, how to explain the disparity of judgments about the speech of the minibus driver in relation to the other professions?

Apparently the terms "conscientious", "normal" and "popular" are usually seen as neutral from a social point of view, and only the label "vulgar" or "affected" seem to have a certain connotation. If we split the four terms grouped before into two sets, this disparity can be explained.

In the case of the doctor, $25 \%$ rated their speech as A, while that of the minibus driver showed $44 \%$ of V. This leads to think that extreme $\mathrm{A}$ is less recognized than $\mathrm{V}$, and that only the latter is considered as widely negative as it was rated that way by 26 of the 60 respondents. Only seven people said that the driver's speech was N, and only two that it was E, indicating the presence of strong social factors in the analysis of language problems.

Conversely, it turns out to be the doctor's speech whose percentage of V is barely $2 \%$; only the case of the secretary is undefined as it shows notable variations on both sides of what is "normal" in the proposed scale.

The above justifies, in some way, the social scale that we proposed. It can be seen that not only does the speakers have an awareness of differences in speech but also the power to relate them to the structure of Chetumal society. The clear result of these three questions cannot be neglected despite the questionable choice of the informants being considered. Now, if we look at each social class separately, the results are also interesting. If we see the behavior of the members of each social class in front of their representatives, the results show great agreement. The lower class considers their own speech as $\mathrm{P}-\mathrm{V}$ in $96 \%$, the middle class as $\mathrm{N}$ in $66 \%$ and the educated sector sees the doctor's speech as A-E in $60 \%$. The P-V type of social discredit factor is present in the group where it has more weight: the uneducated class. If it was thought, at a given moment, that each group would classify the speech of its representative as mostly "normal" it was only an illusion; This shows the veracity of the documented answers and the degree of linguistic awareness of the respondents -especially in the less educated sector, since it was this in which all its members gave their opinion about their own speech, in the other sectors the opinions were lower.

If, on the other hand, it is a matter of evaluating the speech of an alien social group in addition to that of the representative of the sector itself, things change. The critical attitude and self-criticism towards the strange social group and towards the representative himself shows interesting aspects.

The lower class, for example, mostly defines the doctor's speech with A-E values in $54 \%$ (critical attitude), and to that of their representative they give P-V values in $96 \%$ (self-critical attitude). On the other hand, the upper class gives the minibus driver $72 \%$ in the P-V values (critical attitude) and his representative $60 \%$ A-E (self-critical attitude).

The middle class shows percentages that, on the scale, point towards both extremes, the highest being the middle class with $55 \%$ overall (critical attitude) and $66 \%$ in the opinion of the same speakers in the group (self-critical attitude). That is, the difference between both attitudes is $11 \%$, the same percentage shown by the lower class $(96 \%-85 \%=11 \%)$. Only the educated sector does not present differences between the general pattern $(60 \%)$ and the attitude of the speakers of this group towards their representative $(60 \%)$. This means that the speech of this group is the model of the entire population since there are no marked discrepancies between the various opinions of the respondents.

If the analysis continues, certain differences can be found between the opinions of men and women despite the fact that both groups coincide in some respects: for example, neither considered the secretary's speech as "affected". However, the men rated the minibus driver as more vulgar, but the ladies gave more AE values to the doctor's speech $(49 \%)$ than the men $(28 \%)$, for whom the representative of the tall group spoke "normal" (57\%). The least marked difference appears in the secretary's "normal" rating: $60 \%$ men, $50 \%$ women.

In women there is more variation in self-critical judgments than in men who, while being incisive in their majority percentages, tend to standardize their criteria from $\mathrm{N}$ to $\mathrm{AE}$ in the case of the doctor, or from $\mathrm{N}$ to $\mathrm{PV}$ in the case of the driver of minibus. In women, therefore, there seems to be more restraint in self-critical judgments.

Given these evidences, the male self-critical judgment seems more homogeneous, not the female; therefore, the group of women shows a greater sociolinguistic awareness of their speech and that of the other sectors, since their observations are guided by the stigma or social prestige of a certain population of the community. Regarding the critical judgments towards other social groups, both sexes agree in their observations with the inclinations already noted towards one or the other side of the scale. The questions that refer to the ways of speaking badly in certain areas of the city were used to analyze the attitudes of rejection towards the groups "bad spoken". Thus, $65 \%$ of the informants consider that the neighborhoods where people speak badly are Solidaridad, Barrio Bravo, Forjadores, Proterritorio, Payo Obispo and Del Bosque, which are, for the most part, places where people with an economic precariousness live visible.

15 Opinion of an uneducated 25-year-old woman.

16 "They are rude, they shout things to each other and they are not interested in people, but they talk like that." The comment is from a 57-year-old middle-level woman. 
In this regard, the lower class considers that in those places, where many of its members live, they speak badly (75\%); while the educated class shows a higher affirmative percentage (77\%) claiming that these neighborhoods are the cradle of badmouthing, despite the fact that only $94 \%$ of its members have answered the question.

However, it is also possible to find deficiencies in the speech of other neighborhoods. This situation was observed by $25 \%$ of the lower class, $61 \%$ of the middle sector and $17 \%$ of the educated group. These neighborhoods are popular with diverse inhabitants but where people with limited economic and cultural resources prevail.

The analysis of these results shows that there is awareness of social barriers in Spanish speakers in Chetumal in all social sectors, especially in the low and high groups. The first, aware of his sociolinguistic position, locates the incorrect forms in other places as well; the second, defending its privileged position, observes that linguistic deficiencies are mostly found in poor neighborhoods.

The middle class is more measured in this regard. She distributes "bad talk" in all parts of the city (61\%) and not only in the aforementioned neighborhoods (39\%). The reason is undoubtedly their intermediate position that looks both sides of the social scale.

The differences regarding sex are visible. Men distribute their judgments in almost the same percentage in the two options mentioned to them (53\% said that there are neighborhoods where Spanish is spoken badly, $40 \%$ said no); while women were more blunt ( $78 \%$ and $22 \%$ respectively). However, $64 \%$ of the men did not want to live in neighborhoods where people speak badly, $1 \%$ said they did not care and $30 \%$ did not respond; while $84 \%$ of the women mentioned that they would not like to reside in one of those colonies. The educated sector was the most reluctant to live among the humble $(83 \%)$, and $70 \%$ of the uneducated group mentioned the same; while the middle class rejected this possibility by $61 \%$.

It is necessary to clarify that by presenting the concept of "speaking badly" without nuances or definition, the respondents could reject the question due to the lack of precision of its meaning, or could use their subjective personal experience. Fortunately, they chose the second option.

The combined analysis of the five questions results in the following observation: the relationship of linguistic exchange between the different social layers indicates that this does not occur in all directions, but rather from the top down ${ }^{17}$. Not being the objective of the present work to demonstrate how some elements of speech move from one group to another, it is possible, however, to study to what extent the different social levels are capable of accepting foreign elements. The lower sector, being described mainly by the other two groups as P-V, does not contribute much in this linguistic exchange. The stigmatized form of their speech is never taken as a model, and the awareness of this situation is evident because lower-class people "do not care if someone tells them that they are speaking badly. ${ }^{18}$ " If the results of questions 4, 5 and 8 are compared, it is confirmed that most of the popular and vulgar forms reside in humble areas, a situation that, as already pointed out, the uneducated sector is very aware. This group sees in the secretary's speech a certain model that can be imitated $(42 \%$ of $\mathrm{N})$, but not the educated class that observes in this representative of the intermediate sector $33 \%$ popular characteristics when for the group under these they are only $16 \%$. That is, what serves as a model for the less educated sector is discarded by the class with more culture.

The doctor's speech is, clearly, the most appropriate linguistic modality to be imitated; and although the lower sector has given certain negative characteristics to term A, those of $\mathrm{E}$ are certainly higher. The middle class finds more negative elements in the speech of the minibus driver (44\% of V) than in the speech of the representative of the educated sector $(16 \%$ of A). However, this same intermediate class, in terms of the distribution of the speech of the other two social groups in the city (questions 7 and 8), feels that the people of the Campestre neighborhood - where the rich class lives - speak more well normal (66\%), and those of Solidarity or Proterritorio, popular (66\%). That is, their observations change when it comes to qualifying a social group than when that evaluation refers to a single individual who was taken as the representative. His generalizations are more thoughtful, as are those of the other two sectors in identical situations. Only the less educated group increases its percentage by $4 \%$ of A when evaluating the speech of the inhabitants of the wealthy zone who they consider, due to the same negative connotation of the term, pedantic or excessively arrogant -especially women- despite that, as noted before, the speech of the representative of this sector is the most imitable ${ }^{19}$.

The critical behavior of men from the uneducated sector towards the speech of the Campestre neighborhood shows that it is the women -of the same group- who most reject the way these people speak, since the percentage of A in the doctor's speech rises to double when they evaluate this zone of rich people. Men, for their part, see more negative connotations - of A- in the doctor's speech than in that of the neighbors of that colony. Again the observations change when rating an entire social group and not just an individual.

The $\mathrm{V}$ value of the uneducated class visibly lowers its percentage when it comes to evaluating the speech of the Solidaridad and Proterritorio colonies. The comment would be that the speech of the minibus driver is more stigmatized than that of the neighbors of those popular neighborhoods, although the male upper class mentions that in both -both in

17It is a linguistic change initiated sporadically and irregularly that allows correcting certain forms by imitating those used by a higher social group.

18 Comment of a 30 -year-old man who works in a carpentry.

19 Despite the fact that, in the opinion of several of those surveyed, the young people of the Campestre neighborhood are very rude in their way of speaking, that is, very vulgar; vulgarity that is not exclusive to that colony, but the property of a large part of the young Chetumaleños. 
the representative and in the social group- vulgarity prevails ${ }^{20}$, thus showing this sexual group as the one that most rejects this sociolect.

The role of the mass media - especially radio and television- in the Chetumaleña community plays an important role in the diffusion of linguistic trends. Proof of this has been the displacement of the concept of "brata" for that of "pilón"21. a kind of gift -especially sweets- that the landlord gives to the buyer. This displacement is due to the diffusion of the dialectal modality from the capital of the country - a normalized variety - that operates in the regression of the regional or local vernacular and that has come to become a model in the community. In the purely lexical field this situation seems to be more evident, not so in phonetics. The role of television in the dissemination of news and other information is not unknown, and it is also possible that it may function as an important factor in language changes.

However, it was already mentioned that the majority P-V speech of the lower classes does not collaborate in terms of linguistic exchanges from one social class to another; However, how to explain that television can have such an influence on speech if 58\% of those surveyed said that there are programs in which popular or vulgar Spanish is used?

The explanation for this paradox resides - and partially discards this supposed influence - in that in some television programs from Mexico City - most of them - stereotyped forms are sometimes shown that function as social signals and are captured by the respondent, cartoonish ways of speaking of a character whose main objective may be to show certain social differences $^{22}$. In others, the forms of prestige are also presented, but most of them escape the attention of the speaker.

The popular or vulgar character is found by the respondents more in local radio programs than in foreign television, and the statement that the announcers speak badly seems to indicate that the awareness of this situation is clear and that these models, because they are socially discredited, they do not influence anything in everyday communication ${ }^{23}$.

The next two questions are aimed at studying the formal and informal styles ${ }^{24}$ of the respondents. For this, the proposed scale was returned and the informant was asked which type of speech was closest to his in the contexts of work $^{25}$-formal- and home -informal. These responses would result in the vision of an individualized self-critical attitude.

In general, both men and women from the three social strata clearly recognize the differences between a formal and an informal situation, showing majority P-V values for the latter, except for women from the upper sector. Compared to the general pattern that indicated mostly A-E for the doctor's speech, $\mathrm{N}$ for the secretary and P-V for the minibus driver, the individualized self-critical attitude indicates that the majority of all groups speak or pretend to speak normally in both situations. Given this, linguistic indulgence appears as a real fact that results from putting the speaker in front of his own pronunciation.

Regarding the formal style, it is the men of the uneducated group who consider that their speech has characteristics of $\mathrm{E}(7 \%)$ compared to $0 \%$ of $\mathrm{E}$ of women in the same sector. And it is they themselves who maintain that same $7 \%$ of $\mathrm{E}$ in informal speech, although they find $37 \%$ of $\mathrm{P}-\mathrm{V}$ in it, while the ladies only manifest $18 \%$ of this last value, and $27 \%$ in the formal situation. In sum, to be clearer, in this sector it can be seen that discredited forms increase in male informal speech. According to the above, men seem to be more aware that there are different styles in different situations, and they are more concerned with putting aside uncultivated forms and speaking well in formal contexts. Women from the same social strata tend to ignore linguistic correctness and speak with little variation - at least that is what their responses reflect - at home than in their workplace.

The cultured group shows fewer differences. Regardless of whether the N value prevails in both sexes and situations, men again tend to differentiate more between formal and informal. What is striking about women is that they give the P-value $30 \%$ in formal situations and $0 \%$ in informal situations when it was expected to be the other way around. This result could be explained by housewives in the low sector, but not in those in the upper sector. This may be due, among other things, to the surprise of the informant who does not expect that type of question that surely causes confusion and responds full of doubts.

Men consider that their speech is more careful in formal situations and is even careful (37\%), and they do not give any percentage to the P-V value. However, at the informal level the curve descends from normal to P-V (37\%).

The middle sector shows some variation in their responses. Both men and women show normal speech both at home and in the workplace and the same percentage of P-V in both places - although this is higher in women (9\%). In opposition to this, men rate their speech as more careful (A-E 7\%) at work, something that women do not do (0\%). This is the only marked difference. It should be noted that questions 10 and 11 were those with the highest percentage of

20 According to a 50-year-old cultured man, this vulgarity is due "to the environment and to the little education that these people have received". 21 This vernacular form widely used in the sixties and seventies has been gradually displaced by that broadcast on television.

22 I write down some of the television programs that the informants mentioned: all are broadcast from the capital of the country: "Mexican Picardie", "Puro loco". I also cite others that from my own experience I consider clear examples in which a popular and even vulgar Spanish is used: "El chavo", "Zero in conduct", "What happens to us?", "The thing"

23 I think that it will be difficult for them to influence local speech - at least in the academic and colloquial one of some generational and social groups - in ways such as the following taken from a commercial for French fries broadcast on national television: "con esto te podrás llevar un premio bien chido: una buena lana, una bataca o una lira, o una súper nave"; es decir, "con esto te podrás llevar un premio muy bueno, bastante dinero, una batería o una guitarra eléctrica, o un gran automóvil".

24 We understand by style the register conditioned by the communicative situation, that is, by the linguistic use.

25 A definition of social context is not easy to carry out, consider, at least to try to do it, the social, cultural and psychological world in which the speaker acts at any given moment. 
non-response; a situation that highlights the hesitant attitude of the speaker when questioned about his own way of speaking. This absence was more visible in the informants from the lower classes in formal situations, especially in women. This is understandable because this sector is unaware of the different types of speech that the upper class - the only one to answer the two questions $100 \%$ - has or believes they have, and thus their doubts are so many that they prefer not to comment. In the middle sector, the absence was a little less, but also considerable.

When asked about the informal style, the situation visibly changed, and most answered the question.

In summary, social loss of prestige, difficulty in making a self-critical judgment and awareness of a variety of styles are factors that can be observed in Chetumalian speakers. The first has more weight in women in the lower group, the second appears more in the female sex of the lower classes, and the third characterizes men in the lower sector.

Questions 12 and 13 are aimed at certain language learning problems and the importance of speaking well. The lower class considered that it is important to speak correctly (92\%) although this has not been indicated by the parents of $25 \%$ of those surveyed.

The upper class was more concerned and aware of speaking correctly (100\%) and declared that they had been taught this problem by their parents $(83 \%)$. The intermediate social group was less aware than the educated and low in the importance of speaking the language well (88\%) and referred to this disdain for the lack of correction in their linguistic forms by their parents (28\%). On the other hand, women turned out to be more aware of the role of teaching the correct forms of the language than men who received very little education in this regard, especially those from the uneducated group.

Question 14 alludes to the Yucatecan origin of several Chetumaleños. The constant migrations of Yucatecans in the city have had consequences in the particularities of the community's discourse. Everyone knows the migrations of many people from various parts of Mexico to Chetumal; Among these, that of people from the neighboring state of Yucatán is the most widespread.

Those who most perceive some particularity of speech in the children of Yucatecans are the women of the lower class whose ages range between 30 and 50 years. Now, in what is perceived this particularity? The observations lie both in the indigenous Mayan lexicon ${ }^{26}$ used by these speakers, as well as in the pronunciation of Spanish that characterizes Yucatecan speech: articulation of $\mathrm{b}, \mathrm{d}, \mathrm{g}$ as stops in intervocalic position: [ebapóra], presence of glottic cuts: [tu?ermáno], glottalized articulation of certain consonants p ', t', k ', (?' and palatalization of n + j: [kin/jéntos] basically. The nahua lexicon

This means that, despite the respondents belonging to the same dialect variety as the children of Yucatecans, they are able to perceive well the difference in pronunciation between them and those who do not have that origin.

And not only that, they also observe the difference, especially in intonation, between their speech and that of the inhabitants of the Federal District who, according to them, lengthen their words and speak little songs. The conclusions that they all made always referred to phonetic and not lexical aspects. Of course, a single question in this regard is not very significant to frame so many opinions expressed about foreign speech.

Questions 16 and 17 go beyond the borders of the city since they revolve not around the knowledge of the indigenous language of the region: Yucatec Mayan, but about its existence and use in the community. $92 \%$ answered that they do know of its existence, this knowledge was higher in men 30 years and older and mostly in the lower sector. The young women and the upper and middle groups showed less knowledge of the presence of that language. Now, who speaks that language? Opinions are diverse. For the more knowledgeable group, the majority of the inhabitants of the Yucatecan peninsula speak Mayan. His opinion is supported by several studies done in Yucatan; and although today the majority are not Mayan speakers in Quintana Roo, at one time they were in Yucatán and in various places near the geographic limits of that entity: Tihosuco, José María Morelos, Kantunilkín. Product of this situation of languages in contact (Mayan-Spanish) is the singular pronunciation of the Spanish-speaking Chetumale. Considered as an astratum language, the Mayan language not only qualifies Spanish at the lexical level, but has also provided it with a particular phonetic. Proof of this is that a Yucatecan -from the peninsula or almost all of it- is clearly distinguished when compared to other Mexican speakers where there is also a large indigenous-speaking population. His way of pronouncing has notable peculiarities. Perhaps someone confuses a Veracruz native with a Tabasco, or a Poblano with someone originally from Tlaxcala; but you can never confuse a peninsular Yucatecan with a Chiapas or Tabasco. The last two questions refer to this modality more dialect than social. First of all, what is bludgeoning? The majority (33\%) accepted that it is speaking Spanish with a strong accent, cutting words (5\%) and with a Mayan accent $(6 \%)^{27}$. It was mostly men who made such statements and those over 30 from the lower sector. On the other hand, who speaks that way? Opinions, again, are diverse. A high percentage (17\%) said they did not know, another (10\%) mentioned that those from northern Mexico and gang members (10\%). However, the majority assured that this way of speaking is only held by the Yucatecans, especially that opinion is held by those of the cultured sector and men of all

26 Some of these lexical forms widely not used throughout the city are: mucbipollo, muilx, pipií, xik, uix, uixar, xek, bacal, ch'el, meco, mocho, papa zúul, saramuyo, siricote, tucho, turix, xix, chechón, chechonear ,, koliz,, (See Pérez,2000). The Nahuatl lexicon is also present in this border speech, however, being used more than the Mayan languages, it does not characterize any social group as the use of the Mayan lexicon can. (See Pérez, 2006).

27 Here they basically refer to the occlusive articulation of b, d, g, intervocalic and the presence of the glottal cut, glottal joint or "saltillo" typical of the Mayan language. 
generational groups. This general opinion clearly has stigma or rejection overtones; especially for the cultured group ${ }^{28}$, as the other social sectors were less blunt in their opinions.

\section{CONCLUSIONS}

As a member of a linguistic community, any speaker knows which words are socially acceptable and which are not, knows how to discriminate and rank them based on the meaning they have or have had in their multiple life activities, that is, according to use that I gave them. That is, he is aware of this value that words have even though sometimes he is not able to express it.

The degree of linguistic awareness of Chetumaleños is notorious because they are capable of relating differences in speech with social structures. Factors of social discredit motivate negative attitudes in all layers of society, while prestigious variants produce reverse reactions and serve as a model of good talk for the entire population. This leads to the assumption that linguistic exchange occurs mostly from the top down, and that if it is carried out in the opposite direction it is very limited and in markedly informal situations.

It is in the humble neighborhoods of the city where deficient ways of speaking can be found more frequently, there is a wide awareness of this among the entire population, especially in the less educated sector.

The differences between men and women of the same social class are sometimes notorious. In the uneducated layer, they are the ones who most reject the talk of the colonies where rich people live; while men have a more particular and not so panoramic judgment. In other words, the female sector has a certain tendency to generalizations and the male sector is more measured in that sense. In short, the linguistic variations shown by Spanish speakers in Chetumal are notorious, and this notoriety is nothing more than the reflection of a linguistic awareness that is very well situated in all social sectors. Chetumaleños know how to start any conversation with people from different social sectors, and in these talks, everyone's ways of speaking emerge that are sporadically analyzed by the speakers themselves when asked about them. Perhaps only at that moment of answering the applied questionnaire they have been aware of their way of speaking and that of others, but this does not prevent that awareness is always present in all life situations in the community in which they live.

These differences and coincidences can be seen in the following table that summarizes the results obtained after analyzing the data obtained in the surveys.

\begin{tabular}{|c|c|c|c|}
\hline Opinions & Talk about the doctor & Talk about the secretary & Talk about the driver \\
\hline All speakers & $\mathrm{AE}+\mathrm{N}-\mathrm{PV}-$ & $\mathrm{AE}+\mathrm{N}-\mathrm{PV}-$ & $\mathrm{P} V+\mathrm{N}-\mathrm{AE}-$ \\
\hline Speakers about own social group & Low PV+ & Medium N+ & Alto A E + \\
\hline Speakers about alien social group & $\begin{array}{l}\text { Low E A+ doctor } \\
\mathrm{P} \mathrm{V}+\text { driver }\end{array}$ & $\begin{array}{l}\text { Medium E A+ doctor } \\
P \mathrm{~V}+\text { driver } \\
\mathrm{N}+\text { secretary }\end{array}$ & $\begin{array}{l}\text { High } \mathrm{P} \mathrm{V}+\text { driver } \\
\mathrm{E} \mathrm{A}+\text { doctor }\end{array}$ \\
\hline Mens & $\begin{array}{l}\mathrm{N}+\text { doctor and secretary } \\
\mathrm{PV}+\text { driver }\end{array}$ & & \\
\hline Women & $\begin{array}{l}\text { E A+ doctor } \\
N+\text { secretary }\end{array}$ & & \\
\hline Places of evil speak (popular neighborhoods of the city) & Low $\mathrm{P}$ V+ & Medio PV+- & Alto P V+ \\
\hline Places of good talk (elegant neighborhoods of the city) & Low N+ & Medio N+ & Alto A E+ \\
\hline formal style men & Low P V+ & Medio N+ & Alto $\mathrm{N}+$ \\
\hline Formal style women & Low N+ & Medio N+ & Alto $\mathrm{N}+$ \\
\hline Social discredit & Low women + & & \\
\hline Lack of self-critical judgment & Low women + & & \\
\hline Lack of awareness of variety of styles & Low mens + & & \\
\hline Awareness of the importance of speaking well & Low- & Medium +- & High + \\
\hline
\end{tabular}

Sociolinguistic variation and awareness in Spanish speakers on the Mexican border with Belize.

To understand more clearly the stage of Spanish spoken in this border region, it is necessary to base our conclusions on the lexical region, since the use of these spoken forms in the neighborhoods of the entire city can serve to fully show the way in which that Chetumalian speakers conceive the speech of their neighbors who live with them daily and that of their friends who do not live in the same neighborhood as them and who, supposedly, do not belong to the same social class or who, belonging to the same social class, speak like them or like outsiders; These examples serve to find the differences between the vulgar and refined speech of the inhabitants as well as the perception that the same protagonists of the linguistic environment have of them.

Undoubtedly, any speaker is capable of perceiving the way in which people express themselves, and this capacity becomes evident when he is asked directly about the characteristics of the speech of other people with whom he has a relationship and is given to him. They give examples of these speeches when selecting the characters to represent them (the secretary, the driver, the doctor). That is to say, the questionnaire has the purpose of extracting from the same

\footnotetext{
${ }^{28}$ I have had the opportunity to hear not very flattering comments about the pronunciation that the Yucatecans have, not only from those who do not have that origin but also from those who, having it, deny it. That is to say, those born in Chetumal say that they are not Yucatecan -although their parents are and speak "clubbed" -; They are Chetumaleños and they are aware that one should not speak "bludgeoned" like the Yucatecans because they are not.
} 
speech community its opinions about the speech of itself and about that of the social strata that structure it. In this way, samples of diverse speech have been obtained in the different social strata in which certain lexical features that characterize them usually appear. For example, the appearance of the Mayan voices coliz 'pelón' and the morphological hybrid chechón 'lloriquear' in a daily conversation show an eminently popular speech typical of the poor and middleclass neighborhoods of the city. On the other hand, the use of sidereal or didactics in any conversation are samples of a more refined language typical of educated people who live in wealthy areas of the population. The reference to various nahuatlisms comal, zacate, tamal are not exclusive to any social group such as the Mayanisms, and their use is not a symptom of belonging to a popular or cultured type of speech. The results obtained from the designed questionnaire attest to the degree of sociolinguistic awareness that Chetumal speakers have of their language.

The foregoing assumes that sociolinguistic practices do not accept remote work but that these must be carried out in situ under penalty of their conclusions not being accepted because they do not reflect the reality of the sociolinguistic consciousness that a speech community has about its productions of speech everyday.

Through the application of a questionnaire we have been able to extract vernacular and standardized forms from the speaking community of Chetumal that characterize the entire population. An example of vernacular form would bulto be 'purse', 'bag', backpack, 'backpack', 'briefcase'. Bulto - vernacular form - has a use in almost the entire population, that is, it is a speech register that can appear in any sociolect, even in the written form. No store of the Liverpool or El Palacio de Hierro chain would dare to promote their merchandise as "Lucy's" does in the heart of the city: "Costume jewelery in gral. and lumps ", so reads the ad, simply because lumps is a vernacular, a non-standardized form that only the natives of the region know and understand, and although they are the majority of potential buyers, it would be preferred to use bags or backpacks, forms standardized with a broader spectrum of use.

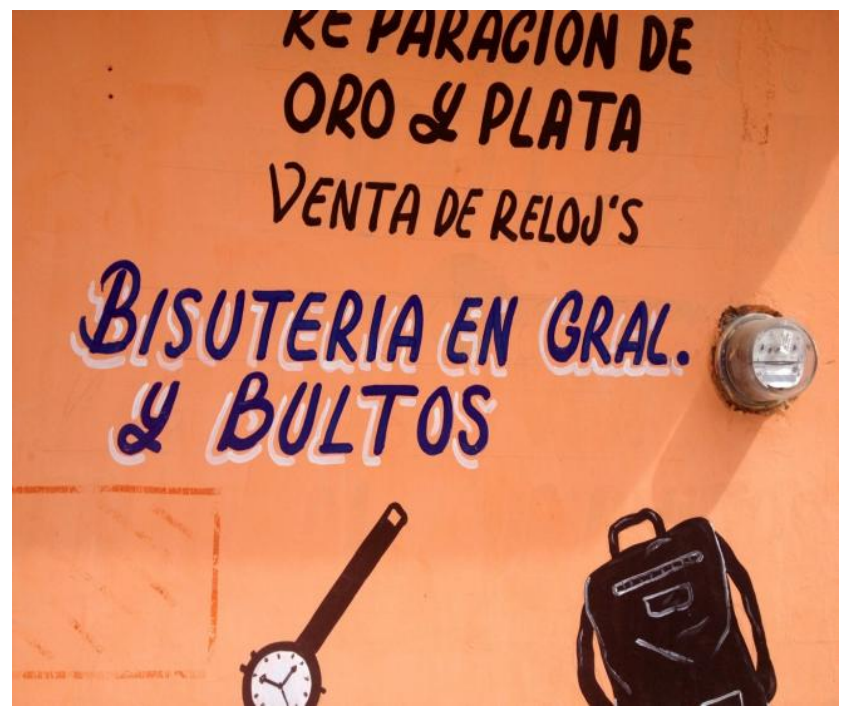

What symptom does this use of lump leave us? 1. That the owner of the establishment is from Chetumal, 2. That the advertisement is intended for the full understanding of the entire native population (even though it bears a drawing of a backpack), 3. That the written record attests to the colloquial use of the voice. This stylistic use of the bulge leads us to consider that every speaker - or scribe in this case- belongs to both a social and a geographical dialect, determined by historical factors not always known to the linguist. And ignorance of these factors tends to hinder a deep analysis of the state of the language being studied. The example of a package is just a sample of the power that the vernacular has in the written record in Chetumal, of the power it enjoys in use, and of the long life that is predicted if its geolectal and sociolectal distribution is taken into account; A more extensive study would be missing to know the styles of use of this word and to guarantee with it that long predicted life. What can be assured is that its use is greater in people over 50 years of the social sectors with less schooling and with a precarious or barely stable economy. That is, his use is a symptom of the speaker's vernacularity and indicates that he is a speaker born in the city of Chetumal parents from whom he has acquired the voice that is already part of his active lexicon.

The use of standardized forms can characterize the social group with the highest education and the people who live in residential areas, although they can be found at different social levels because they are in common use. Standardized forms such as logistics, autonomous, delicate, etc., do not characterize any social group. Perhaps the use of paraphernalia, buried, unison if it is a symptom of a careful speech of people with studies, forms that never appear in the records of popular speech.

\section{REFERENCES}

[1] García de Diego, Vicente. (1946). Manual de dialectología española, Madrid, Gredos.

[2] García, Francisco. (2019). Fundamentos críticos de sociolingüística, España. 
[3] Falcón and Mamani. (2017). “Actitudes lingüísticas en contextos interculturales: población asháninka bajo chirani” Revista de Lingüística Teórica y Aplicada, Concepción Chile), 55 (1), I Sem. pp. 95-115.

[4] Kubarth, Hugo. (1986). "La lengua como juego social. Conciencia sociolingüística del porteño” Thesavrvs, XLI, p. 187-210.

[5] Lara, Luis. (2016). Teoría semántica y método lexicográfico, México, El Colegio de México.

[6] Pérez, Raúl. (2000). "Vitalidad y significación sociolingüística de los mayismos en el español de Chetumal” en Lingüística mexicana, no. 2 P. 181-195.

[7] Pérez, Raúl (2006) "Índice de nahuatlismos en la frontera mexicana con Belice” en Estudios de lingüística, Universidad de Alicante, No. 20, p. 305-316.

[8] Pérez, Raúl. (2016). "La herencia lingüística canaria en la frontera mexicana con Belice” en Revista de Filología Española, (96) 1, p. 149-168.

[9] Vallarta, Luz. (2001). Los payobispenses, México, Universidad de Quintana Roo/CONACYT.

Raúl Arístides Pérez Aguilar, the son of Belizean parents, he was born in the Punta Estrella neighborhood of Chetumal, Quintana Roo in 1958. He is a Doctor in Hispanic Linguistics from the National Autonomous University of Mexico. Author of the essay books: The inverted triangle (UQROO, 1999), Linguistics and Literature Studies (UQROO, 2001), Chetumal speech (UQROO / IQC, 2002), Writing strategies (UQROO, 2006), Speech from Quintana Roo. Materials for his study (UQROO, 2011) and more than thirty articles that have appeared in various cultural and scientific magazines in Mexico and Europe, he is also the author of the novels Los ecos nomadas (Caligrama, 2020) and 1692 Motín de indios (Universe of letters, 2021). In 1997 he received the Gabino Barreda Medal awarded by UNAM and in 2011 the Gonzalo Guerreo Prize awarded by the Municipality of Othón Pompeyo Blanco to outstanding Quintana Roo intellectuals. He currently works as a professor-researcher at the University of Quintana Roo and is a corresponding member in Chetumal, Quintana Roo, of the Mexican Academy of Language. 